\title{
On Musical Performance as Play
}

\section{Gabor Csepregi}

\begin{abstract}
A B STRACT The purpose of this article is to complete, and build on, the theories of a certain number of scholars, chiefly philosophers of previous generations, and a few eminent performers of classical music who all bring to the fore the essential link between music and play. Because of their impulse value and appealing character, tones and other elements of the performance could generate a playful attitude in the musicians. Play is understood as a reciprocal interaction with something that plays with the player: indeed, tones play with the musicians and, reciprocally, the musicians play with them. While engaging in a musical play, they draw on the remarkable creative abilities of their body, namely its spontaneity, sensibility, and "imaginative" anticipation. The satisfaction provided by the playful activity comes, in part, from the possibility of experiencing the body as a source of creative power and original performance.

KEYWORDS play, music, aesthetics, body, musical performance, Buytendijk, Plessner
\end{abstract}

While there are many aspects of our experience of music that have been thoroughly described and discussed today by serious students of aesthetics, not enough attention has been paid to the fruitful relationships between music and play. ${ }^{1}$ The more recently published analyses of musical listening, work, and performance either ignore altogether the subject or advance fleeting remarks about it. ${ }^{2}$

If play is present in all corners of our life, can this form and quality of activity be achieved in the domain of music - perhaps more so in an exciting performance of classical music than in a computer or card game that turns out to be dull and boring? If so, what could give to the rendering of a symphony or a sonata a playful character and make of the whole or part of the musical performance a genuine play? ${ }^{3}$ More importantly, perhaps, what prompts a musician to adopt an attitude of play? But, first, let us see why philosophers of music are advised to pay attention to the close connection between play and musical performance?

\section{Why Should Philosophy of Music Be Concerned with Play?}

Many forms of play are carried out and shaped by a certain number of bodily capabilities. When we play on a musical instrument, we perform a great variety of bodily movements and we rely on the body's ability to create sounds and respond to sounds. Our body is lived as an expressive "medium" between our intention and the actual performance. While our musical intention finds its expression, we do not perceive our body as an object of our will and conscious representation. It is experienced as an 
unfolding behaviour, a series of meaningful movements, through which music is created.

The most important analyses of play highlight the characteristics and effects of bodily movements. Whether they refer to the playful contest or the game of make-believe or the seeking of vertigo, they recognize that the to-and-fro movement of the body is an essential part of the mode of being of play. ${ }^{4}$

Considering a musical performance within the sphere of play does not automatically imply that the analysis will focus on the musician's body. Conversely, describing the bodily experience of the musician does not inevitably entail a thorough study of the playful character of the performance. Yet if we see and appreciate the playful elements in the musician's activity, we could be more inclined to perceive and appreciate the affinity between making music with an unconcerned ease and the body's indwelling abilities, and thus bring additional observations to the already published works. ${ }^{5}$ If, in this article, I intend to emphasize the playful aspects of musical performance, it is chiefly, but not exclusively, due to the positive consideration that the creativity of the body and the ensuing musicality could receive from both the observing thinker and the performer.

Hugo Rahner was one of those philosophers who pointed out that a playful activity engages both our spiritual and bodily abilities. A spiritual skill, such as the detachment from fear and concern or the awareness of an image, finds its expression in a bodily gesture and its tangible outcome. Play is "a process whereby the spirit 'plays itself into' the body of which it is part" and "whenever the mastery of the spirit over the possibilities presented by the body has in some way attained its perfection". There is a desire to seamlessly integrate the conscious purpose of expressing an idea and a particular bodily capability: "The happily playing child, the virtuoso playing upon his instrument - and how few in fact really 'play' upon it! - the genius whose work flows from his fingers with effortless ease of one playing a game - all these are but realization of man's deep-seated longing for a free, unfettered, eager harmony between body and soul". 6

Although Rahner tends to emphasize, in all forms of play, the mastery of the spirit over the possibilities of the body, experience tells us that the smooth agility and elegance of the bodily skills may equally sustain a carefree inner attitude and the creation of artistic imagery, making thus possible a satisfying communicative performance. For some, the complete integration may be the result of submitting, as much as possible, 
the body's powers to a voluntary control. The musician should not forget, as they contend, that his chief task is communication: he has to transmit the composer's musical ideas to the listeners. His body must not get in the way of his conscious effort of placing the essence of music before the audience. However, as we shall see, these powers could become highly beneficent and formative elements of the musical performance itself and the task is fostering their normal functioning by adopting a receptive and adaptive attitude and telling the conscious and evaluating self to get out of the way.

Clearly, Rahner is far from trivializing the art of a musician, or any other similar artistic performance, by treating it as a board game played on a Sunday afternoon. The artist who plays upon his instrument is keen to adopt a serious yet light-hearted attitude; he produces sounds with ease and detachment even if he is aware of the seriousness of his purpose and the gravity of his mission. When the player gives himself with the utmost concentration and absorption to the musical performance, his serious attitude also becomes manifest. Hence, as Hans-Georg Gadamer aptly remarked, "seriousness is not merely something that calls us away from play; rather, seriousness in playing is necessary to make the play wholly play". ${ }^{7}$ Only the musician who is fully immersed in a play is able to experience a feeling of synchrony with all elements of his activity: the score, instrument, other musicians, his own bodily movements, or the ambient space.

According to Leonard B. Meyer, the performer's expressive deviation from the normal and regular way of playing is a guarantee of creativity in music. In absence of such a playful approach to the score, the performance is nothing but a rigid and mechanical process. Meyer views the performer as a true creator "who brings to life, through his own sensitivity of feeling and imagination, the relationships presented in the musical score or handed down in the aural tradition which he has learned". ${ }^{8}$ Play here is conceived not merely as music's detachment from practical and goal-oriented concerns, nor as a structural quality of a particular passage or movement, but as the performer's creative and personal dealing with the music itself. Meyer's understanding of expressive play, together with the views of F. J. J. Buytendijk, is the most inspiring for my own analysis since he discovers the play in the performer's "creative role" and ability to introduce "ornamentations" or "deviations", regardless of the music's inherent aspects. In this article, I endeavour to complete Meyer's observations on this subject by stressing and describing the role of the musician's body in play.

It is worth emphasizing that we should not view play and playfulness 
as synonymous with light-heartedness, carelessness, or frivolity. ${ }^{9}$ Even if it is carried out with effortless spontaneity, play is one of the noblest and most serious human activities. Music's formal elements, as well as the purposelessness of tones, make of both the listening and the performance a rich and deeply captivating experience. Playfulness has to do not only with the delight of making music for its intrinsic value but also with the sympathetic bodily involvement in the coming and going of the sounds, the ease and creativity of the performance itself, without which music loses its appeal and communicative capacity and fails to elicit enjoyment. Therefore, it seems to me highly important to emphasize the adoption of a playful attitude while making music because it makes of a musical performance a lively, innovative, and enchanting reality.

In their written texts or verbal declarations, performing musicians list and analyse a good number of skills that they must develop and posses, but seldom mention or praise the playful reading of the score. It seems that, in their eyes, playing on an instrument and playing with a puzzle are two entirely different kinds of activity. Perhaps bringing a playful expression into the performance or creating the equivalence between mastering a musical instrument and playing on and with the instrument is simply transforming this lofty art into a trifling activity, not requiring any aesthetic sensibility, sense of order, intellectual understanding, and rigour. After all, it took several centuries to change the perception of the public with respect of the role musicians play in the society and to come to treat and respect them as exceptional individuals endowed with superior gifts. Why should they accept their prominent and almost divine activity becoming "merely" a play?

Yet, there are also artists who happily and explicitly consider the whole or part of musical performance a play. Here is an eloquent statement made by a timpani player: "Most people go to work, but we go to play. There has to be an element of play. If you have a lousy conductor, you feel like you're going to work, but by and large, I feel I'm going to play, as in child's play: it's the joy and innocence and being totally immersed. That is part and parcel of the concentration you have to have. But you have to be willing to let yourself go". ${ }^{10}$ Sándor Devich, former second violinist of the world-renowned Bartók String Quartet, claims that a string quartet performance is "a beautiful, noble, interesting, thrilling, and difficult game, in which only those can participate who know how to play - who know and accept the rules and the conventions". He evokes the spontaneity and joy of play that leaves the sweat and pain behind and eliminates the chance of performing mechanically and without soul. ${ }^{11}$ 
Gabor Csepregi

\section{The Role of Play and Body in Musical Performance}

How can, then, music making be understood and lived as a delightful and captivating play? Let us first focus on the total immersion in playing, the sympathetic involvement with tones, the unfolding of music through a dynamic and reciprocal relationship between the performer and the tones produced by an instrument or the human voice.

THE PHENOMENON OF PLAY

In all play, there must be something with which the player plays; one cannot play alone. Play is a reciprocal interaction with something that, on its turn, thanks to its mobility, expressive quality, or dynamic and sensory possibility, plays with the player. Therefore, the player is relieved of the strain of repeated initiatives, finds himself drawn into the play and captivated by the playful interaction itself. In our case, the most important "partner" of play is the tone. Just like the capricious movements of a ball or a marble or a wheel, the lively succession of tones holds the performer in its spell, exerts on him an attraction, generates a playful response and altogether sustains a spontaneous tendency to play. ${ }^{12}$

Another important aspect of this reciprocal interaction is the explicit or implicit awareness of the dynamic qualities and possibilities of the object of play. This object has to be as it were an animated and "living" reality: one cannot play with something completely devoid of a "life" or mobility of its own. Therefore, a ball, a wheel and a spring are our favourite playthings because they immediately suggest a response to our anticipated or virtual movement. But many other objects - a pencil, a chair or a piece of cloth - could be perceived with their dynamic possibilities and suggestions, and exert a fascination on us, as long as they are divorced from their habitual significance. Thus we are ready to respond to their attraction and find ourselves to be drawn into a structure of reciprocal initiatives and adaptations.

\section{PLAYING WITH TONES}

In a similar fashion, tones may become objects of play in as much as they exert a strong appeal on us; they reach our ears and, if we are available to their suggestions, invite us to play with them. It is not surprising, therefore, that one of our earliest ludic experiences is the play with sounds. When the infants hear their own sounds, they perceive them as successive "invitations" to produce other sounds. ${ }^{13}$ The desire to play with sounds or sound sequences remains with us forever. Helmuth Plessner correctly pointed out that sounds communicate an "impulse value" (Im- 
pulswert), a compelling "affective appeal" (gefühlmässige Wirkungen). ${ }^{14}$ Because sounds detach themselves from their source, they penetrate us, take hold of us, and we are delivered to their influence. Communication through sounds is quite different than it is through visual objects. ${ }^{15}$ (A spy film or a game of football that we watch without sound lacks life and, obviously, fails to produce the desired effect.) Hence also the powerful "sociological effect" of sounds: they unite people and create a sense of community, for both good and evil purposes. ${ }^{16}$ Plessner relates the volume and impulse of rhythmically articulated sounds to the phenomenon of "insistence" (Eindringlichkeit). No other sensory element makes its way and soaks into us as does the sound: it provokes resonances at levels perhaps deeper than the visual, olfactory or tactile qualities. It acts upon us through our bodily sensibility and influences our attitude and movement. While we hum a song or improvise a tune on a musical instrument, the pathic character of our momentary auditory experience elicits a response and provides an incitement for the ongoing play with sounds.

Temporal realities, the tones of music have a remarkable impulse and dynamic value: a tone calls for another tone; their succession is motivated by the tones themselves, by their inherent volume, intensity, extension, resonance, tension, and resolution. All the ingredients of music - melody, variation of rhythm, succession of colours, contrast of chords, resolution of a dissonance - are the extension of this dynamic quality or impulsiveness of tones.

"The musical play", says Buytendijk, "is playing with music that plays with us". ${ }^{17}$ The play in music consists of producing tones that, through the sense of hearing, return to the musician and, due to their vivid and dynamic quality, elicit other tones. The tones press upon the musician, communicate an impulse, resonate in him, and invite him to produce other tones. It is the pathic quality of the tones, their binding and appealing character, that personally affects the performer and compels him to respond in some way. The tones present a range of dynamic possibilities and these, together with the score and the directives communicated by the conductor or fellow musicians, provide the incentive to create a musical continuity with relative freedom and inventiveness.

Playing with the tones entails, therefore, the awareness of a development and the anticipation of the closure of a whole, a still undisclosed end. We may relish the auditory moment as the tones aimlessly follow each other. Or we may apprehend the tones in their strict and lawful relations as the move to an end. Music lies between a formless progression and a rigid and regulated architecture of notes. Whatever is the product 
of momentary choice, the possibility of playful inventiveness or deviation occurs within the limits provided by the rules and conventions. No activity of playing, or listening to, a musical piece would be possible in absence of the awareness of continuity and some formal rules. ${ }^{18}$

For Plessner, the dynamic association and reciprocal interaction between tones is a form of play. "Their own play is a play with us and our play with them". Our integration into this play must be "disinterested" and non-participatory. ${ }^{19}$ Being part of this play calls for an ability to follow the playful development of tones and impose a control over the bodily movements that the tones provoke. "Musicality is nothing else than the faculty of mastering our being taken along through the tones. First the detachment from this "being taken along" makes the sonorous lines understandable". ${ }^{20}$ Thanks to the refusal to surrender to the impulsiveness of tones that listeners or performers are truly able to be part of, and follow or generate, with an objective and "cool" view, the dynamic play of tones.

\section{PLAYFUL ATTITUDE OF ADAPTATION}

I am, however, convinced that the fine bodily responses to tones are not always an obstacle to a deeper musical understanding. Erich Rohmer was probably right when he asserted, not without a slight exaggeration, that we truly appreciate music and "feel it in all its depth", when we dance to it. ${ }^{21}$ With the performer, a certain degree of surrender to his bodily impulsiveness is not only unavoidable but also advisable. When the body's resources are made available and effectively used while making music on the instrument, the playful modification and appreciation of tones could occur more or less frequently. Therefore, we may view the ability to allow oneself to be guided by the development of tones, and respond to their suggestions and affective appeal, as a significant, although not easily achieved, aspect of the musicality of the performer.

It would be misleading to think that playing on the piano or the cello consists of assembling previously learned tactile sensations and movement patterns, and to apply these on an objective representation of an indifferent instrument. The musician's performance is no different of the motor accomplishment of a skier or a swimmer. The movements are a more or less successful adaptation to the requirements of a global situation, in which the instrument and the music to create play a prominent role. "The would-be student of the violin", points out Erwin W. Straus, "must have a good ear, for it is the acoustical form of sound, its aesthetic quality, that is to direct the activity of his hands". ${ }^{22}$ 
Adapting his movements to the demands of the music, a performing musician has to faithfully play every single note of the score and attentively follow and respect every indication of the composer. Faithfulness to the score does not mean that the performance has to be cold, mechanical, schematic, and, ultimately, boring. Champion of textual fidelity, Gunther Schuller has recognized that the strict objectivity of an interpretation is never without subjective qualities that talent, education, and experience foster. "A certain amount of subjectivity and the predilections of our personality will always come into our performing and colour it, in subtly distinctive ways. And that is good and not to be deplored". ${ }^{23} \mathrm{I}$ would add to this excellent observation that a playful attitude of adaptation to the coming and going of tones could also yield a more personalized but no less respectful realization of a musical work.

PLAYFUL MODIFICATIONS OF MUSIC

This personalized line of approach consists of introducing into the performance minor expressive modifications. The most important source of this subtle modification is, as we have seen, the tone itself. The conductor, for example, who enjoys a certain limited interpretive freedom, plays on an orchestra: his movements produce the sound whose quality, together with the score to follow, produces, on its turn, further movements and the subsequent slight modification of the sonorous performance. The responsive orchestra may then play the notes slightly faster or slower, louder or softer, or introduce other dynamic, sonorous, or timbral shades. "Conducting", writes F. J.J. Buytendijk, "is, in its innermost being, the example of the player". ${ }^{24}$ The same response to a musical impression may occur while playing on a piano or on any other instrument. Here, too, the playful performer could react to a rhythmic or harmonic figure with a finely differentiated dynamics or accentuation. We may mention here the subtle change or "distortion" of the rhythm or tempo that the musicians call agogic accent or effect. Its use depends on the talent and temperament of the pianist, as well as on the style of the music, and requires a sense of spontaneity and improvisation. Its effect and beauty comes from the ability of making this alteration natural and hardly perceptible. The actual temporal length of tones, whether they are connected or separated, gives music its articulated character. The articulation is not merely the result of the long period of practice. It could comprise the unusual solutions created, without a previous preparation, by the momentary disposition of the musician. Equally, the performer could spontaneously respond to numerous other variables such as the audience, acoustics of the 
hall, prevailing atmosphere, or quality of the instrument, and even the rebound of the keys of the piano, and, by articulating phrases or musical ideas, subtly and without significant alteration, translate these reactions into the music. Since the tones themselves continue to suggest accents, shades, or groupings, as well as very delicate lengthening or shortening of rests, it is possible to repeat such patterns effortlessly and spontaneously. There can be a two-way flow of initiative and response between the player and the various elements of musical diction with which he plays. The audience and hall themselves may become musical instruments and, as the musician plays them, they also could exert an influence on his performance. ${ }^{25}$

Organs and harpsichords have registers. Their number allows the player to create multiple combinations and offer the possibility of exploring a great variety of tone colours. Some might take up a cautious attitude and try to avoid a "historically deformed performance". Others believe, however, that the registers have been provided so that the player could exploit their possibilities to the fullest and play with and through them in the same manner as their colleagues did 300 years ago.

The score seems to be a fixed and relatively rigid representation of music. Yet, just as much as the written text of a theatrical work, it is also a series of living symbols that, thanks to its possibilities of realization, could inspire the play with tones. The musician does not need to deviate from the written notations. He just has to recognize that, for example, a musical construction appears to be a melody suitable for singing and make the instrument "sing" it playfully. Or he has to perceive in rhythmic figures a danceable tune and bring out and stress the pulsating movement. The score then becomes animated through the awareness of the vocal or dance-like character of the music. The recourse to musical or pictorial images, such as the rise and fall of the voice, enhances this awareness. The playful performance then consists of reading the score and realizing the music with "singing heart" or "dancing spirit". ${ }^{26}$

Perceptibly, a lively dance movement awakens more easily the playful attitude towards music than a melancholic adagio. Yet the playful interaction with tones, instruments, or atmospheres does not occur only when the performers find themselves in a happy and joyful mood. All sorts of styles and forms could elicit in the musician the readiness to render music with creativity and subtleties of expression as long as an unconcerned and relaxed relation to the tones and other variables prevails. What matters, above all, is the adoption of an attitude of availability to respond to the various impressions that may reach the performer and, above all, 
the surrender to the expressive and inventive capabilities of the body. The control of the body is doubtless necessary during the long period of learning and acquisition of the skills. It is just as essential to focus on, and respect of, the indications of the composer. But once the adequate mastery of movements is acquired and the intellectual and technical abilities are fully developed, the creative performer could trust his body and allow these abilities to propose subtle changes and embellishments. In short, as the violinist Sándor Végh so aptly recommended, "during his play, the artist must perfectly liberate his body". ${ }^{27}$

SENSIBILITY, SPONTANEITY AND TACTILE ANTICIPATION

OF THE BODY

A singular decisive factor in the momentary and playful modification of music is the musician's ability to echo vivid and penetrating impressions, to resonate to the appeal of meaningful sonorous events. The words "echo" and "resonance" refer to the receptivity and responsiveness of the body, to its sensibility. The body is able to resonate to a stream of impressions and respond to them with fine movements. It is important to note that this resonance does not have to be a conscious response. While playing on a violin or a piano, the tactile contacts with the instrument or the exposure to a friendly or indifferent audience, could unconsciously evoke affective responses in the body and induce qualitative changes in the performance.

The playful activity also calls for, and gives room to, the spontaneous impulses of the body. Notwithstanding the prescriptions of the notations and the desire to implement previously learned and practised movements, the realization of a piece implies that a discrepancy may occur between a specific intention and an unusual solution arising from the body. The musical form is then no longer produced in a strict sense but discovered and the resulting emphasis, accent or dynamic level may elicit an effective surprise in the performer. When, for example, the pianist introduces a longer rubato, an unexpected phrasing, or executes differently a trill, he relies on his hands" singular potential for invention, variation, and novelty concealed within the already acquired skills. He creates the surprising effects that, by way of retroaction, facilitate and encourage the continuation of the creative and spontaneous activity. ${ }^{28}$

John Blacking was doubtless right in saying that "music-making is derived from certain biologically given capabilities". ${ }^{29}$ Some of these capabilities are the sensibility, natural spontaneity, and memory of the body. Let us now briefly consider the "imaginative power" of the hands and the 
rest of the body, which is not to be equated and confused with the visual representation of an image. When playing on a piano or a violin, music originates in, and leads to, an active mode of sensory experience, touching. ${ }^{30}$ While touching an object, we both anticipate and receive specific tactile qualities. The anticipation of these tactile sensations constitutes just as important a part of a manual activity as are the actual tactile impressions. But the tactile anticipation of touching a key on the piano or a string through the bow is also tied to the "projection" of a movement. The hand as it were "imagines" movements to the same extent as it anticipates sensations, though the musician is seldom conscious of these projections. (The anticipatory imagination becomes conscious when, for example, the piano's action fails to respond to the speed or force of the pianist's attack or a string breaks or a mistake is made.) It is possible that the anticipated gesture deviates from what is prescribed or suggested by the score or from the previously learned and executed movement form. A momentary feeling, induced by an atmospheric impression or the quality of an already created sound, may be the cause of such a modification of the anticipated movement and the corresponding real execution.

Thus the playful variations, introduced into the performance by the hands, find their source and explanation, in part at least, by the surging of unexpected movements on the instrument and these are inspired and triggered by fresh bodily feelings. It is the body's discriminative sensibility that relates to whatever seems meaningful in the surroundings and the body's "imaginative" faculty invents the form and intensity of the contact with the instrument and the resulting sound sequences. Hence the happy insistence of certain musicians to remain open to a wide range of signals and to "respond to all kinds of things, what your ear tells you, or even how the audience is reacting can translate into how you are playing". ${ }^{31}$ Hence also the beneficial advice of "getting out of the way", of trusting the body's sensibility and intuitive anticipation, and, in this manner, of letting the body's indwelling abilities to shape an artistic performance. ${ }^{32}$

\section{PLAYING WITH OTHERS}

There are obvious differences in making music in an orchestra or playing in a string quartet. The orchestral performer does not have the same freedom to play with the tones, as does a chamber or a solo musician. When, for example, everybody is called to play short notes, the orchestral bassoon player cannot take the liberty to bring into the music slightly longer note values. Yet, as a tuba player confessed, during the perfor- 
mance of Stravinsky's Rite of Spring, he did dare to playfully "split one of the high notes", creating the laughter of all the viola players and the concerned look on the conductor's face. ${ }^{33}$ Notwithstanding the necessity to put aside one's personal taste and adapt the performance to the style of the orchestra, "there has to be an element of play", to quote, once again, the timpani player. As one of his colleagues, a French horn player, put it, "You can have that in a Haydn symphony, just the way you turn a phrase. Just a little stretching thing in there, one phrase when the minuet comes back, and putting a little thing in it, it just sort of gives you, 'Ahh.' It's like a sneeze; it feels really good. It's fun to play that way". ${ }^{34}$

Playing in a string quartet is, for many active musicians, is an exhilarating experience. The successful temporal synchronization of the four musical events require that each member plays his own part and, at the same time, takes into account the performance of the others. As Alfred Schütz has shown, such a co-performance entails the awareness of the measurable time (the basic tempo as indicated on the score), and the sharing of the lived and inner temporalities, in which both his own part and that of the others unfold. ${ }^{35}$ The lived inner time is the ongoing, subjectively experienced flow of musical events. The musician can feel the very same tempo as fast or slow and thus hit or miss the character of a piece. The violinist hears and anticipates the cellist's way of living the music while he knows that the cellist follows, with a similar kind of awareness, his own play. This complex process of communication and "tuningin relationship" is hardly possible without sharing space with the other members of the quartet. The synchronization of musical performances, the reciprocal sharing of the inner time of the co-performers, is rooted in the immediate sensory experience of the partners' bodily expression. A playful interaction may occur during this subtle communicative process. Through a subtle bodily movement, the violinist may playfully communicate his feeling about a particular tempo and request either an adaptation or a response to the suggestion of change. This conversation may last until the chosen tempo not only respects the composer's indication but, thanks to its adjustment to the character of the piece, also is felt right, natural, tasteful, and playfully creative for all members of the quartet.

\section{The Musician as Player}

When it is a question of speaking about the characteristics of a musical performance, it is not uncommon to make the distinction between executing and creating a piece of music: performing without missing a note and making of the performance "a living creation". ${ }^{36}$ The executing 
musician faithfully and correctly carries out the composer's indications. While creating a musical work, the musician reproduces the musical score and, at the same time, makes his "personality" felt; he brings to the music his feelings, imagination, and creativity. Both kinds of accomplishment - the flawless accuracy and the compelling musicality - are needed and should receive due recognition. As Roger Sessions remarked, "without fidelity, the performance is false, without conviction, it is lifeless". ${ }^{37}$

BRINGING LIFE TO MUSIC

What brings life and conviction to the performance, according to Sessions, is the "musical impulse" and "energy" of the musician and not merely his ability to understand and translate the composer's intentions. In respect of these two vitalizing factors, Sessions evokes the feeling for rhythmic articulations and an acute and flexible sense of tempo. ${ }^{38}$ Béla Bartók saw in the perpetual variability and individual expressive modifications the concrete and desirable manifestation of the performer's vitality and energy, without which the performance is nothing but a mechanical and artificial production. ${ }^{39} \mathrm{I}$ am inclined to view the playful tendency of the musician to respond to the invitations of the tones and numerous momentary variables (audience, acoustics, or instrument) as another source of vitality and "conviction". It is, in part at least, his sense of play that fills the music with life because, by "sharpening notes", or "putting a little accent" or introducing "a slight change in tempo", the performance is accomplished with a certain degree of unpredictability, individuality, and spontaneity. ${ }^{40}$

It also permits the player to fully give himself, without being preoccupied with the already played parts and the upcoming overall achievement, to the present moments of the performance. ${ }^{41}$ Although they are correlated to a vast musical construction, the musical figures, however short or long they are in duration, played in the present, are no longer merely incomplete sequences receiving their significance only from future and past musical elements. They are perceived as important and meaningful achievements in themselves, almost as if they had some sort of extension and density. ${ }^{42}$

\section{AWARENESS OF THE BODY}

Musicians may also experience the elementary enjoyment related to the process of moving the hands on the keyboard or in relation to any other instrument (tuba, viola, or timpani), namely what the anthropologists 
call "functional pleasure". This singular glow of satisfaction does not depend on physiological processes alone but also on how the musician experiences his body, his motility, and his relationship to the sounds, the concert hall, and the listeners. It could also silence the excessive concern about technique and foster relaxation and "openness to a wide range of signals" ${ }^{43}$ I suspect that playing on an organ could occasionally provide the musician with this kind of enjoyment: as his buttock covers only a very small part of the bench, the organ player literally embraces the instrument and pleasurably senses the dancing movements of all his limbs.

There are no serious artists who do not insist on the importance of ease and naturalness while playing on an instrument or fail to evoke reasons for combining concentration with relaxation. But only some of them stress the close relationship between the state of this unconcerned and leisurely relaxation and the reliance on the formative powers of the body. It is worth quoting, in this respect, the thoughts of Claudio Arrau on the risk of becoming too conscious of, and preoccupied with, technique, and not learning how to relax the hands and the rest of the body: "I found out very early that playing in a relaxed way makes one more creative - because it is so natural; because the whole body is involved; because there is unity of body and psyche". "With the singers it's the same thing. When they are relaxed, and just let the sound come out, they don't lose their voices until very late. The muscles acquire a wisdom of their own". ${ }^{44}$

A musician needs both consciously acquired and well-ingrained technical skills and spontaneous and bodily impulses. The pianist should acquire the former during countless hours of practice and dare to make use of the latter during public recitals or concerts. This is the advice of György Sándor who, in his useful book, repeatedly emphasizes the value of "subconscious processes" and the uninhibited introduction of "spontaneous, improvisatory, and creative elements" into the performance. ${ }^{45}$ Whether these elements are to be considered truly playful depends on the presence of ease, risk, unpredictability, tendency to repetition, as well as on the readiness to respond to the attractive possibilities presented by the music and the prevailing conditions in the concert hall.

Although it is too easily ignored or forgotten, singing, playing on an instrument, and listening to music, are, above all, bodily activities and, when accomplished in a relaxed and receptive state, they create a sense of unity with the body. ${ }^{46}$ And when music is performed in the spirit of play, this involvement and awareness could be further heightened. Hence the particular significance of the musical performances in which play becomes the guiding principle. Because it calls for a diminution of 
conscious control, the playfulness adopted by a musician gives room to the body's creative capabilities - the wisdom of the body.

The playful attitude generates, as two musicians put it, a "wonderful sense of detachment" and a "wonderful sense of joy in performing". ${ }^{47}$ This enjoyment comes, in part at least, from the experience of their body. The actualization of creative spontaneity and sensibility makes them feel that the body is truly their own or, perhaps the other way around, as if they were taken over by their body's inventive abilities.

All too often, especially during the long period of learning or the daily interaction with people and objects, artists perceive their body as an instrument to control and mould, and even to manipulate, or simply as a resistance to overcome. In many other non-artistic areas of their life, they are invited to distrust the sensory contact with their environment, especially the tactile contact with concrete realities, leading to the gradual degeneration and atrophy of their organic capabilities. The bodily disengagement is strongly reinforced by the widespread tendency to use technological devices and to relate to people and objects in abstract and quantitative terms. While playfully making music, the senses are fully engaged, the movements are versatile and inventive, and the body is lived with a delighted sense of equivalence and synchrony, as a source of vitality and possibilities, a creative force that responds judiciously to impressions and explores new expressive means. The artists no longer confront it and feel themselves truly in harmony with it. It is this experience of oneness and creativity that our educational endeavour has to understand and promote, in music as well as in other forms of artistic activity, and, if it is possible, in all affairs of our daily life.

\section{Notes}

1. I would like to thank Mr. Alan Walker and Mr. László Gombos, musicologists and historians of music, and Mr. Miklós Spányi, keyboard player, for their most helpful comments on the subject of this article.

2. Roger Scruton's comprehensive book, which contains many valuable things, briefly refers to play in relation to the intrinsic value of culture. It fails, however, to consider the playful character of the performance. A happy exception is Alexandra Pierce whose book devotes a chapter to the "spirit of play". Pierce recommends that musicians recollect, imagine or execute playful movements and, then, let their musical performance be permeated and inspired by "a heightened mixture of absorption, focused skill, and exuberance", as well as "friskiness and creativity", "the pleasures of not planning ahead, of taking chances, of being 
bold enough". See Roger Scruton, The Aesthetics of Music (Oxford: Clarendon Press, 1997), 457-58; Alexandra Pierce, Deepening Musical Performance through Movement: The Theory and Practice of Embodied Interpretation (Bloomington: Indiana University Press, 2007), 178-86.

3. It is perhaps unfortunate that English and certain other languages use exactly the same term to describe both the act of communicating the composer's musical thoughts and the act of creating sounds playfully, playing with musical sounds. Johan Huizinga, however, finds it "quite natural" that, in some languages, the manipulation of musical instrument is called playing: "making music bears at the outset all the formal characteristics of play proper". Homo Ludens: A Study of the Play Elements in Culture (Boston: The Beacon Press, 1955), 42 and 158. The biologist Adolf Portmann asks whether the language, by calling the contact with a musical instrument playing, does not want to provide a true simile of the actual form of this activity. "Spiel und Leben", in Entlässt die Natur die Menschen? (Munich: R. Piper \& Co., 1971), 252.

4. In addition to the works of Huizinga, Buytendijk, Gadamer, and Rahner, mentioned in this article, see Roger Caillois' classical study, Man, Play, and Games, trans. Meyer Barash (Urbana, Il: University of Illinois Press, 2001).

5. In his extensive study, Stan Godlovitch analyzes many aspects of the musical performance, even reflects on improvisation and creative playing, but does not come to conceive that playing a piece of music may be considered a playful activity. In his eyes, a performance requires a wide variety of physical skills, allowing the musician to control the production and quality of sounds. "Every musical effect stems immediately from some physical control the player has over the vibrating object." However, due to the attraction that the sound or another reality exerts on the player, a playful activity comprises an interplay of initiative and adaptation, control and trustful surrender. In his equally thorough analysis, Paul Thom asserts that the musicians can place an individual stamp on their realization "through their personal physical qualities", and thus "giving life to the musical work," but the reader still needs to know what are those qualities and how they creatively shape the realization of music. Stan Godlovitch, Musical Performance: A Philosophical Study (London: Routledge, 1999), 55; Paul Thom, The Musician as Interpreter (University Park, PA: The Pennsylvania State University Press, 2007), 85 .

6. Hugo Rahner, Man at Play, trans. Brian Battershaw and Edward Quinn (New York: Herder and Herder, 1967), 7.

7. Hans-Georg Gadamer, Truth and Method, 2nd rev. ed., trans. and revised by Joel Weinsheimer and Donald G. Marshall (New York: Continuum, 2004), 103. Read also the fine reflections of Vladimir Jankélévitch, Music and the Ineffable, trans. Carolyn Abbate (Princeton, N.J.: Princeton University Press, 2003), 66. 
8. Leonard B. Meyer, Emotion and Meaning in Music (Chicago: University of Chicago Press, 1957), 199.

9. In a different context, Eduard Hanslick already formulated this concise definition: "Music is play (Spiel) but not frivolity (Spielerei)". On the Musically Beautiful: A Contribution towards the Revision of the Aesthetics of Music, trans. and ed. Geoffrey Payzant (Indianapolis: Hackett Publishing Company, 1986), 82.

10. John T. Partington, Making Music (Ottawa: Carleton University Press, 1995), 144. The italics are mine. This book is a collection of a wide range of thoughts, stories, and principles on musical practice and performance. They are the results of the interviews conducted by the author with principal players and wellknown concert pianists associated with leading Canadian orchestras.

11. Sándor Devich, What is the String Quartet? (Budapest: Editio Musica, 1985), 16 and 209.

12. For my understanding of play, I turn chiefly to F. J. J. Buytendijk's analyses. The thorough concept of play developed by Hans-Georg Gadamer was much influenced by the penetrating insights of Buytendijk. See F. J. J. Buytendijk, Wesen und Sinn des Spiels: Das Spielen des Menschen und der Tiere als Erscheinungsform der Lebenstriebe (1933), reprint edition (New York: Arno Press, 1976); HansGeorg Gadamer, Truth and Method, 102-10.

13. Wilhelm Dilthey remarked that if the child plays with the variations in sounds, it is also due to a feeling of inner vitality, a "surplus of energy". "High and low pitch, strength and rapidity in the succession of tones, and even variations in vowels, stand in regular relations to the child's mood. They provide the basis for musical expression, certain natural elements of every language [...] as well as accentuation and rhythm in speech". Poetry and Experience, Selected Works, vol. 5, eds. Rudolf A. Makkreel, Frithjof Rodi (Princeton, N.J.: Princeton University Press, 1985), 108.

14. Helmuth Plessner, "Zur Anthropologie der Musik", in Gesammelte Schriften, 7, Ausdruck und menschliche Natur (Frankfurt am Main: Suhrkamp Verlag, 1982), 190.

15. See also the fine observations of John Dewey, Art as Experience (New York: Perigee Books, 1980), 237-39.

16. See Erwin W. Straus, The Primary World of Senses: A Vindication of Sensory Experience, trans. Jacob Needleman (New York: The Free Press of Glencoe, 1963), 377-78. See also his phenomenological study on "The Forms of Spatiality", in Phenomenological Psychology (New York: Garland Publishing, 1980), 3-37.

17. F. J.J. Buytendijk, "Das menschliche Spielen”, in Kulturanthropologie, eds. Hans-Georg Gadamer and Paul Vogler (München: Deutscher Taschenbuch Verlag, 1973), 96. The composer and pianist Moritz Eggert voiced a similar opinion in a recently given interview. For the composer, he claims, "the play with tones is 
the starting point". Max Nyffeler, "Musik braucht den spielerischen Impuls. Der Komponist, Pianist und Performer Moritz Eggert im Gespräch”, Neue Zeitschrift für Musik, 2011, no. 1, 10-11.

18. See Erwin W. Straus, The Primary World of Senses, 323-24.

19. In the original and much longer French version of this contribution to the anthropology of music, published in 1936, Plessner uses the verb integrate. "Le proper jeu est un jeu qui nous intègre et nous les intégrons à notre jeu". "Sensibilité et raison. Contribution à la philosophie de la musique", in Gesammelte Schriften, 7, Ausdruck und menschliche Natur (Frankfurt am Main: Suhrkamp Verlag, 1982), 180.

20. Helmuth Plessner, "Zur Anthropologie der Musik”, 198.

21. Erich Rohmer, De Mozart en Beethoven: Essai sur la notion de profondeur en musique (Arles: Actes Sud, 1998), 15.

22. Erwin W. Straus, "The Lived Movement", in Phenomenological Psychology, 52 .

23. Gunther Schuller, The Compleat Conductor (New York: Oxford University Press, 1997), 21.

24. F. J. J. Buytendijk, Das Menschliche: Wege zu seinem Verständnis (Stuttgart: K. F. Koehler Verlag, 1958), 147.

25. Yehudi Menuhin calls this spontaneous and immediate reaction to a musical event (a note, a sequence of notes, a phrase) distortion. In his analysis of the entry of the violin in the Beethoven Violin Concerto, he shows that, by holding and accenting certain notes, and by strictly observing the basic rhythmic pulse of the movement, a distortion provides music with vitality and expressive power. Yehudi Menuhin, "Improvisation and Interpretation", in Theme and Variations (New York: Stein and Day, 1972), 35-46.

26. See the essay of the composer and musicologist Lajos Bárdos, "Singing Instruments", in Selected Writings on Music, trans. Alexander Farkas and Kata Ittzés (Budapest: Editio Musica, 1984), 7-20.

27. Sándor Végh, "Musik als Erlebnis", in Mensch und Gestaltung, Eranos-Jahrbuch, 29, ed. Olga Fröbe-Kapteyn (Zürich: Rhein-Verlag, 1961), 319.

28. See Heinz Heckhausen, "Entwurf einer Psychologie des Spielens", in Das Kinderspiel, ed. Andreas Flitner (München: R. Piper \& Co., 1978), 153.

29. John Blacking, "The Study of Man as Music-Maker", in The Performing Arts: Music and Dance, eds. John Blacking and Joann Wheeler Kealinohomoku (The Hague: Mouton Publishers, 1979), 5.

30. The famous violinist and conductor Yehudi Menuhin judiciously compared the handling and playing of a violin to "a process of caress and evocation". Yehudi Menuhin, William Primrose, Violin and Viola (London: MacDonald and Jane's, 1976), 9. 
31. John T. Partington, 143.

32. The body's ability to resonate, act spontaneously and anticipate movements and sensations are treated at greater length in my book The Clever Body (Calgary: University of Calgary Press, 2006). See also the illuminating essays of Richard Shusterman on somaesthetic skills and experiences: Thinking through the Body: Essays in Somaesthetics (New York: Cambridge University Press, 2012).

33. John T. Partington, 172.

34. John T. Partington, 152. The italics are mine.

35. Alfred Schütz, "Making Music Together. A Study of Social Relationship", in Studies in Social Theory, Collected Papers, vol. 2, ed. Maurice Natanson (The Hague: Martinus Nijhoff, 1964), 159-78; see also Eleanor Stubley, "Field Theory and the Play of Musical Performance", British Journal of Music Education 12 (1995), no. 3, 273-83.

36. John T. Partington, 58.

37. Roger Sessions, The Musical Experience of Composer, Performer, Listener (Princeton, N.J., Princeton University Press, 1974), 78.

38. Roger Sessions, The Musical Experience, 83-84.

39. Béla Bartók, "Mechanical Music", in Essays, ed. Benjamin Suchoff (Lincoln: University Nebraska Press, 1976), 298.

40. John T. Partington, p. 150-51.

41. See F. J.J. Buytendijk, Wesen und Sinn des Spiels, 10.

42. See the still useful work of Gisèle Brelet, L'interprétation créatrice: Essai sur l'exécution musicale, 1, L'exécution et l'œeuvre (Paris: Presses universitaires de France, 1951), 177-95.

43. John T. Partington, 142.

44. Joseph Horowitz, Conversations with Arrau, 2nd ed. (New York: Limelight Edition, 1992), 118 and 128. The italics are mine.

45. György Sándor, On Piano Playing: Motion, Sound and Expression (New York: Schirmer Books, 1995), 183-91 and 220-26.

46. See Anthony Storr, Music and the Mind (New York: The Free Press, 1992), 149.

47. John T. Partington, 26 and 143. 